\title{
高齢者の認知特性を考慮した運転能力評価システムの開発*
}

二瓶 美里 ${ }^{* 1}$, 小竹元基*1, 鎌田 実 $^{* 2}$

\section{System for Assessing Driving Ability of Elderly People}

\author{
Misato NIHEI ${ }^{*}$, Motoki SHINO and Minoru KAMATA \\ ${ }^{* 1}$ the University of Tokyo Dept. of Mechanical Engineering \\ Hongo 7-3-1, Bunkyo-ku, Tokyo, 113-8656 Japan
}

The automobile has an important impact on the daily lives of elderly people and their ability to participate in society. However, the deterioration of physical skills caused by aging is also a cause of vehicular accidents. In this paper, we conduct research into the cognitive function on driving ability, and propose a method to evaluate the driving ability of elderly drivers. The proposed system that the system is a computer simulator rather than an actual on-road driving experiment evaluates the ability to follow a road, the ability to avoid obstacles, and the ability to escape from unexpected dangers. To identify the operating characteristics and define an assessment index, 102 people over the age of 65 were surveyed on their driving attitudes. The investigation showed that the tasks and assessment index, and based on this system, another 92 elderly people participated in evaluation tests. The results showed there was a significant difference between elderly and younger drivers in terms of road-following and obstacle-avoidance ability. In addition, an assessment index with a five-level rating system, based on the characteristics of elderly drivers, was proposed.

Key Words : Elderly Driver, Car License, Development

\section{1. 緒言}

高齢ドライバが第一当事者となる自動車事故は増加傾向にあり，その原因として加齢による機能低下が運転能 力に与える影響が指摘されている(1).ここでいう運転能力とは自動車の運転に必要な知覚・認知, 状況判断・意 思決定，操作行動の複合的な能力であり，加齢による感覚機能や認知機能，運動機能の低下により不安全な運転 行動が引き起こされると考えられている(2)(3). 例えば, 視覚機能が低下寸ると信号や対向車, 歩行者の気付きが遅 れることがある．認知機能が低下寸ると，たとえ対象物が見えていた（知覚していた）としても，それが障害物 であることを認知できず，回避することができないこともある．また，判断や遂行機能が低下するとカーブ走行 や車線変更などが多い環境では，複数のタスクを一度にこなす必要があるため適切な回避が困難になる．運動機 能が低下寸ると頸部や上腕に関節可動域の制限がある場合には，後方を確認しながら行う車庫入れがしづらくな ったり，ハンドル操作がスムーズに行えなくなる場合もある。こうした加齢による機能低下が運転能力に与える 影響が明らかになりつつあるが，単純に加齢による機能低下では説明できない運転能力の低下も存在寸る．行き

\footnotetext{
*原稿受付 2011 年 3 月 29 日

*1 正員, 東京大学大学院工学系研究科（T113-8656 東京都文京区本郷 7-3-1）

*2 正員, 東京大学高齢社会総合研究機構

E-mail: mnihei@sl.t.u-tokyo.ac.jp
} 
先忘れなどの記憶機能低下に関連するものや，頻繁に信号や標識を見落とすといった注意機能低下に関連するも のである.これらの運転能力の低下には，主に認知一判断プロセスを滞らせる何らかの問題が生じていると考え られている，その原因の一つとして近年，認知症の関与が指摘されている(4)(5).

認知症による機能低下は加齢に伴う機能低下とは異なり，進行すると身体機能は急激に衰える傾向がある．そ のため, 自分の能力を自覚できずに不安全でありながら運転を続ける高齢者は多く, 運転を断念する判断基準と して運転に関する心身機能を定量的に把握し，高齢者の自覚を促すことが求められている．しかし，いずれの報 告においても認知症や認知障害による運転能力の変化を定量評価するまでには至っておらず，特に軽度の認知症 や軽度認知機能障害(MCI)は単なる老化との区別が難しく, 運転可否の判断が難しいのが現状である. そこで, 本研究では, 加齢や軽度認知障害の影響により低下寸ると考えられる運転能力に関連する課題を作成し, 高齢ド ライバの運転能力を定量的かつ短時間で評価可能なシステムを開発することを目的とする.

\section{2. 運転に関する制度の現状と高齢者の運転特性の実態}

\section{$2 \cdot 1$ 運転に関する制度}

2002 年 6 月施行の改正道路交通法から免許取り消し要件として認知症が規定された. しかし，この制度によっ て免許を取り消寸には, 高齢者本人が症状を自覚して自発的に診断を受け認知症の認定を得なければならないが, 認知症は自覚症状が現れにくいほか, 初期では認知症であると判断しにくいため本人の自発的な返納は少なく, 家族からの相談がきっかけの場合が多いと言われている(6(7). 警察庁によると, 2004 年末時点での運転免許保有 者数は 930 万人であるが, そのうち 30 万人程度が認知症であると推定されており, 高齢者の交通事故増加に伴い 認知症，またはその疑いのある高齢者による交通事故も増加していると考えられる(2).

そこで同法改正により，70 歳以上の高齢者が免許を更新する際には高齢者講習の受講が義務付けられた．この 講習の内容は, 教習所において座学および実技の講習とシミュレータなどを用いた適性検査を受けるものである. しかし，この目的は能力低下の自覚を促寸ものであり，これによって不合格や免許失効になることはないため， 運転断念のための明確な基準とはなっていなかった. その後 2009 年 6 月から 75 歳以上を対象に高齢者講習時に 記憶力や判断力を判定する講習予備検査 ${ }^{(8)(9)}$ の項目が追加された. 検査の結果, 記憶力や判断力が低下していると 判定され，かつ実車講習において信号無視や一時不停止などの特定の交通違反がある場合には専門医の診断を受 けることが義務付けられることになった.

しかしながら，こうした検査でも特に軽度認知症者やMCI においては，運転者自身が能力を的確に把握し，運 転を自発的に断念寸る際の判断基準とはなっていない.したがって，これらを踏まえた能力を定量的に評価可能 な手法や判断基準が必要であると考える.

\section{$2 \cdot 2$ 高齢者の運転特性}

高齢者の運転特性は，事故統計やヒヤリハット事例に関する非高齢者との比較によって知ることができる．ま た，高齢者を対象とした実車やシミュレータを用いた実験結果から得られた知見からも，高齢者の運転特性が明 らかになっている(10).ここではそれらの結果を踏まえて本システムで計測する必要のある運転特性の抽出を行う.

\section{$2 \cdot 2 \cdot 1$ 事故・ヒヤリハット事例}

交通事故統計における高齢ドライバと非高齢ドライバの分析報告 ${ }^{(11)(12)}$ から, 高齢者は信号のない交差点での事 故や出会い頭の事故割合が高く, また，規模が小さい交差点や見通し不良，信号無視(赤信号の見落とし), 踏切 不停止の割合が高いことが明らかになっている．また，財団法人交通事故総合分析センターの操作誤りに関する 事故分析報告(13)から，高齢者の割合が高い事故はペダルの踏み間違い事故であることを明らかにしている．さら に，これらの操作不適事故につながる人的要因として，非論理的な行動を引き起こす「慌て」「パニック」がエラ 一要因の一つであり, 走行環境に応じた判断・予測が必要であることが示唆されている，一方，ヒヤリハットデ 一タにおける高齢ドライバと非高齢ドライバの分析報告 ${ }^{(1)}$ から，人や自転車が飛び出してきて事故になりそうに 
なった，走っている前の車に接近し過ぎて追突しそうになった，前の車が急ブレーキをかけて事故になりそうに なったなど急な状況の変化に対する判断の遅れに関する特徴が報告されている.

\section{$2 \cdot 2 \cdot 2$ 車線追従と緊急回避}

宇野は，実車による車速変更実験から高齢運転者は車速調整と車線追従能力が低下しており，速度が高いほど その傾向が強くなることを明らかにした. この原因として情報処理容量の低下が考えられると報告している(14). また，楊らは，カーブ走行時に高齢者は長く制動を続けカーブの頂点まで制動する傾向があり，また，修正操舵 が多いことを明らかにしている．この原因として，コースを忠実にトレース寸ることに集中し，前方コースに対 する予測の不足や操作遅れが原因ではないかと考察している ${ }^{(15)}$. 同じく宇野は，ドライビングシミュレータを用 いた交差点における車両飛び出しに対する緊急回避実験の結果, 高齢者は個人差が大きく, 回避成功には一般ド ライバより $0.15[\mathrm{~s}] \sim 0.35[\mathrm{~s}]$ 長い余裕時間が必要となることを報告している ${ }^{(16)}$.

\section{$2 \cdot 2 \cdot 3$ 高齢者の運転特性}

前述の事故事例やヒヤリハット分析報告の知見から, 高齢ドライバは(1) 信号のない交差点での事故や出会い 頭の事故が多い，(2) 規模が小さい交差点や見通し不良での信号無視や踏切不停止が多い, (3) カーブの修正操舵 が多い，(4) 車速度調整と車線追従能力の低下寸る，(5) 飛出しや走っている前の車に接近しすぎる，前の車が急 ブレーキをかけた時の判断遅れがある, (6) ペダルの踏み間違いがあることが分かった. また, その要因として, 知覚機能を含む認知の遅れが生じること(1)(2), 前方コースに対する予測の不足や操作遅れがあること(3)(4), 急 な状況の変化に対応寸る判断の遅れや慌て, パニックによるエラーが生じること(5)(6)が分かった. したがって, 高齢ドライバの運転特性とは，加齢による認知機能（知覚・注意能力）の低下に加え，判断能力の低下（正常な 判断ができず事故を未然に回避することができないこと）を含む複合的な機能低下が事故原因となる可能性があ ると捉えることができる.

\section{3. 予備検討および運転能力評価システムのコンセプト}

\section{$3 \cdot 1$ 運転に要求される能力}

高齢者の認知機能低下や認知症の特徵を踏まえて運転に必要な能力を定量的に評価するには，運転においてど のような能力が要求されるかを考慮する必要がある. 黒田ら ${ }^{(17)}$ による人間の情報処理モデル(図 1$)$ にると, 人間 は行動を起こす際, まず, 感覚から得た情報の中から, 優先して処理する情報を選ぶ前処理が行われる. 優先順 位の低い情報は, 短期記憶として一時的に待機させられる. 優先順位に従って, 情報は長期記憶と照合されて判 断が行われ，決心して操作につながる．これらの各段階のうち，高齢者の運転特性と関連づけられるものは，認 知機能 (感覚, 前処理) や判断機能の低下である. また, 認知症によって特徵的かつ急激に衰えるのは, 注意機 能 (情報取得と処理), 記憶機能（短期記憶, 長期記憶）と判断である. しかし，これらの機能は互いに密接に関

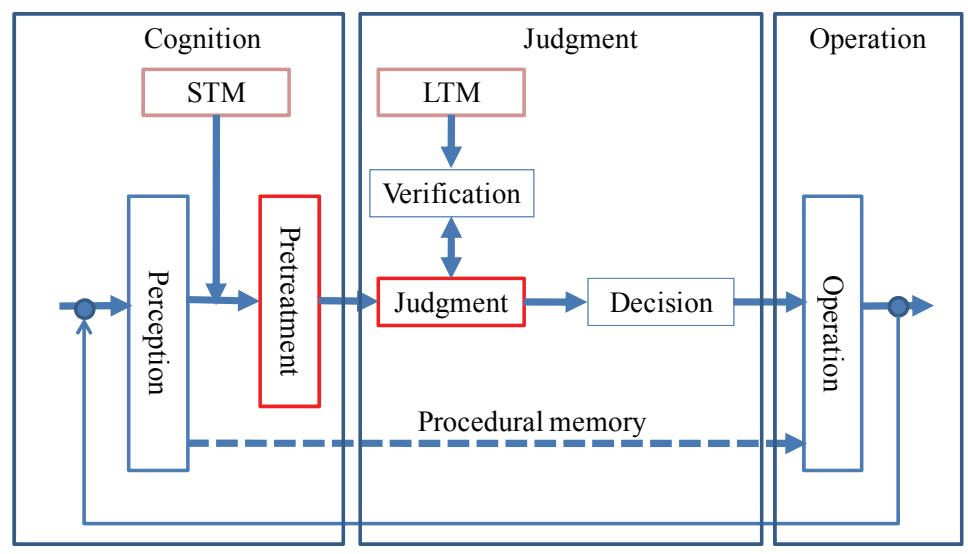

Fig. 1 Information Processing Model (Kuroda's Model ${ }^{(17)}$ ) and issue of the assessment system 
係しており，それぞれを別々に定量化することは困難である．よって，認知機能（注意機能，記憶機能），判断機 能を運転行動と関連付けながら総合的に評価することが必要である. 以後, 運転に関連する認知機能, 判断機能, 注意機能, 記憶機能を合わせた能力を本稿における運転能力と定義する. 本研究ではこの運転能力に注目し, 認 知症であるかどうかではなく, 加齢による認知機能の低下も含めて運転するための能力があるかどうかを判断し, それに合わせて危険さの方向性やレベルの分類を行う.

\section{$3 \cdot 2$ 運転能力を評価する手法}

運転能力の評価に適した手法を検討するために，既存の測定手法の特徵を整理する．自動車の運転に必要な 運転能力を評価する方法のうち，高齢者を対象とした客観的な評価方法としては，実車を用いて運転スキルや視 線行動などを評価する方法 ${ }^{(18)}$, シミュレータを用いて実車に近い運転状況を構築し, 運転行動を検証する方法 ${ }^{(19)}$ ，運転行動をある程度簡略化した簡易的なシミュレータを用いて認知・心理特性を評価する方法 ${ }^{(20)}$, 運転に 必要な認知・心理特性について臨床評価ツールを用いて評価する方法(21)などがある.

\section{$3 \cdot 2 \cdot 1$ 現在実施されている運転能力の評価手法}

本研究では高齢者の増加に伴い運転免許更新を希望する受講者が増加することを考慮し, 講習などにおいて 多人数を対象とし, 複数のテストを必要としない簡易なシステムを目指寸こととした. 現在の運転免許更新時 講習では運転行動を簡略化した簡易的なシミュレータである CRT 運転適性検査が用いられている，運転適性検 查では，主に反射的筋肉的反応速度（単純刺激の呈示に対寸る反応）, 注意の集中・配分機能（中心視野や周辺 視野への反応）, 反応の正確さ・認知判断機能（アクセル・ブレーキ選択反応における誤反応）などを測定する ことができる. その傾向として，高齢ドライバは若年ドライバと比較し，次のことが明らかになっている．単 純反応速度は若干遅く, ばらつきや反応むらが大きい. 注意の集中・配分については中心部より周辺部刺激に 対する見逃し反応数, 反応時間が大きい. また, 認知・判断機能についても誤反応が多い(22).

しかしながら，それらの機能が低下していたとしても，機能低下を自覚していれば無理な運転をせず速度を 落とし，より注意を図る等の方法で安全な運転を維持することができる，一方，各機能が滞りなく機能してい たとしても予測できない状況に対して即時の対応ができないと，不安全な運転行動や危険をまねくことになる. このような機能の補完的な要素も含めた総合的な能力や予測不可能な危険に対応する能力は，事故を未然に防 ぐための重要な運転能力であるが，前述の評価手法では再現しにくいため確認することが困難である.

\section{$3 \cdot 2 \cdot 2$ 認知機能の低下と運転能力に関する研究}

加齢による機能低下に関わらず認知機能の低下と運転行動との関連性に着目した研究では, 認知機能低下と事 故頻度に関する長期的な調查，医学的な指標を用いた機能低下群と高群の比較，画像診断による自動車死亡事故 の原因検証などのアプローチがある，対象疾患について見ると，脳卒中後遺症などの高次脳機能障害によって障 害部位が比較的判別しや寸く進行性の疾患ではないケースに対して, 運転継続の可能性を臨床的に検討する事例 (23)や, アルツハイマー病などの進行性疾患における軽度, 中等度のケースに対して, 運転断念の促しや断念時期 の検討をする事例がある(24). また, 認知症高齢者を対象として実車走行や運転シミュレータにより測定された運 転能力と医学的認知症判断指標 (MMSE (Mini-mental State Examination), CD-R (臨床認知症評価法) ) や認知機 能測定指標（TMT （Trail Making Test, UFOV （Useful Field of View）等）(25)(26)などを用いて評価する事例報告も 見受けられる.これらはいずれについても運転行動の結果と認知機能に関連する指標の比較検討であり, その検 查には時間がかかり, 検査者のスキルや労力が必要となる. また, 本人にかかる精神的な負担も大きいと考えら れる.

\section{$3 \cdot 3$ 運転能力評価システムのコンセプト}

本研究で開発する運転能力評価システムの設計要件としては, 1 種類の検査により総合的な運転能力を判断可 能であること, 事前に判断できない課題を与えることによる失敗からの対処するプロセスの観察が可能であるこ と, 簡便で短時間で実施可能であることを要件とした。 また，システムで運転能力を評価するために必要な課題 として次の 3 項目を設定した. 
・大まかな先を読んだ追従性（周辺視野予測を含む）

・近くを見た細かな追従性（回避動作の的確さ）

- 突然の障害物に対する反応（失敗と回復）

これらは現行の運転適性検査，安全態度検查，動作機能検査では検出することの難しい失敗と回復(予測不可 能な危険への対応)に関する課題や追従課題に焦点を絞り，運転行動に必要な思考と判断プロセスを測定するも のである．具体的には，運転能力が必ず要求されているタスクとしてある目的を達成するための操作中に何らか の失敗をする状況を作り，その失敗の後，もとの状態にまで回復させタスクを考える．本システムに要求される 機能を次に示す.

・失敗をしてもとの状態にまで回復するというタスクを安全に行うために，実際には自動車を運転しないこ と.

- 高齢者でも寸ぐに操作でき，身体的・心理的負担が軽いこと，また，実験装置の操作慣れの程度によって 結果が変化しないために簡易な装置で操作が単純であること．ハンドルなどの入力装置に対して条件反射 してしまって，失敗が起こりにくくなることを避けるために，運転の要素は含むが，実際の運転とは入力 装置や表示が似ていないこと.

上記の要求機能を満たすために，装置の構造を次のように想定した．また，図 2 に装置の概念図を示す．

・ 表示はパソコンの画面 1 つのみであること.

・画面内に映すものは道路，空，地平線と障害物のみで，街並みなどは表示しないこと．

- 入力装置として，横方向はジョイスティックを左右に動かすことで入力する．前後方向や速度コントロー ルは設定しないこと.

本研究で提案した運転能力評価システムによって，これまでの運転能力評価や検查方法では困難だった $2 \cdot 2 \cdot$ 3 節に示した高齢者の運転特性に関連した運転能力の測定が可能になり, 短時間で簡易に認知・判断に関する複 合的な運転能力評価が実現すると考える.

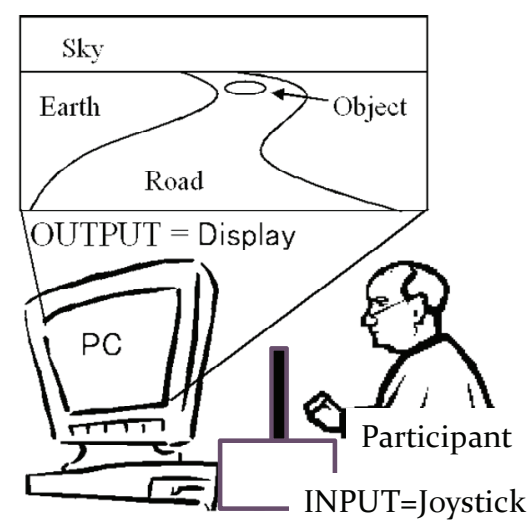

Fig. 2 Assessment System of Driving Ability

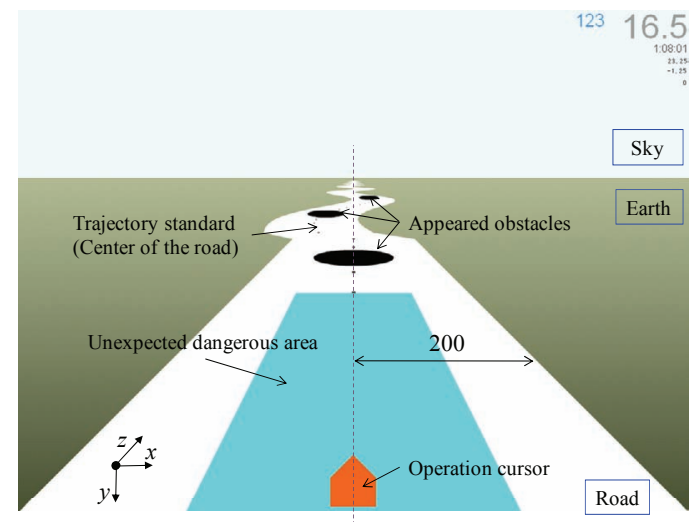

Fig. 3 An example of operation screen

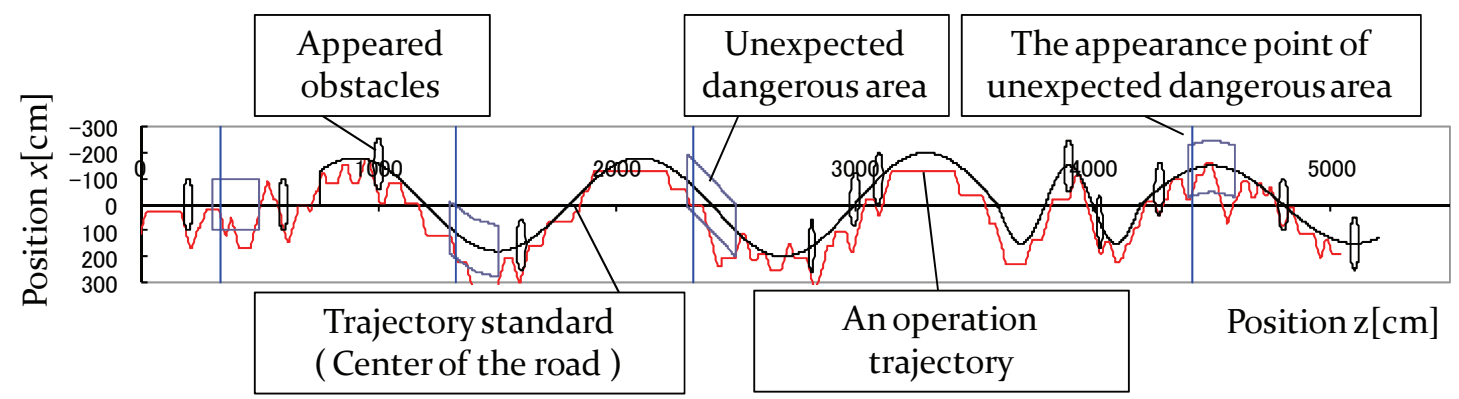

Fig. 4 An operation trajectory 


\section{4. 運転能力評価システム}

\section{$4 \cdot 1$ 運転能力評価システムの概要}

前述のコンセプトを基にシステムの開発を行った．開発環境は Macromedia 社 Flash®を用い，ラップトップ型 パソコンなどの小型 PC(12.1 型を基準とする)で動作するものとした．操作方法はジョイスティック (8 点接点式), 速度は一定とし自動スクロール画面とした．また，操作時間は 180 秒とした．図 3 にシステムの操作画面の一例 を示す，画面に表示されるオブジェクトは走行走路を単純化したもので，道路，空，地平線，障害物のみであ る. 画面中央下部に操作カーソルがあり, 円形の障害物(黒)と矩形の危険地帯(水色)が出現する. 操作カーソル はジョイスティックを用いて左右操作のみを行う. 図 3 に操作軌跡と課題出現位置の全体を示す. 3 次元空間座 標 $(x, y, z)$ においてコースの全長は 50[m], 走路幅は 4[m], 障害物は円形（直径 2[m]）および矩形 $(2[\mathrm{~m}]$ ）とし, その透視変換座標 $(x, y)$ をスクリーン座標系として設定した。 また，スクロール速度は $60[\mathrm{~cm} / \mathrm{s}]$ 一定とした．タス クの種類は主に 3 種類とし，それぞれの具体的な内容を決定した．それらの内容を表 1 に示す.

\section{$4 \cdot 2$ 評価項目決定のための検討}

評価内容は，接近してくる障害物の認知（顕在化した危険）と回避行動，予期せぬ危険の認知（顕在化してい ない危険）とそれらの回避行動を評価することとした，具体的な評価項目の作成については，高齢者を対象とし た実験を行い，それらの操作特性を分類することで決定する．評価項目を作成するにあたり，高齢者を対象とし た操作実験を行い，特徵的な操作軌跡の認められた 102 名（平均年齢 $71.9 \pm 5.72(\mathrm{SD})$ 歳，男性 70 名，女性 32 名） の操作軌跡を特徵別に分類した．高齢者は 65 歳以上の男女であり，K 市で実施した高齢者を対象とした健康診 断を受診した者のうち，希望者の中から自動車の運転免許を所有している者を優先して公募した，その際，調査 内容や質問を理解できかつ返答できることを条件とし，研究の内容や趣旨について口頭および書面で十分説明し たうえで本人の同意のもとに実施した.

操作の結果は, 次節に示寸評価基準に基づき, 操作軌跡を定性的に観察することによって特徵的な操作特性を 抽出した. また，認知機能との関係を調べるために，MMSE スコアが 22〜26 点以下である軽度認知障害疑い

（N=30）についての特徴的な操作についても調べた．なお，MMSE は，認知機能や記憶力を測定するための簡 易的な認知機能検查である. 検査内容は対話形式で対象者の見当式や記憶力などを問い, 30 点満点の点数とし て認知機能を評価するもので，27〜30 点が正常，22〜26 点が軽度認知障害疑い，21 点以下が認知症などの認知 機能障害の可能性があると言われている(27).

Table 1 Tasks presented in the system for assessing driving ability

\begin{tabular}{l|l}
\hline \hline \multicolumn{1}{c|}{ Task } & \multicolumn{1}{c}{ Detail of the task } \\
\hline $\begin{array}{l}\text { Road-following, } \\
\text { prediction }\end{array}$ & $\begin{array}{l}\text { There is dotted line along the center of a test road and the participant is tasked with joining the dots } \\
\text { using a cursor. The track has straight section and nine curves indicated by signs (order-disorder). The } \\
\text { cursor velocity in the direction of forward movement is constant. }\end{array}$ \\
\hline $\begin{array}{l}\text { The participant manipulates the cursor to avoid obstacles (color black), which are located in the } \\
\text { prediction and } \\
\text { obstacle avoidance } \\
\text { center of the road and have a diameter half that of the road width. There are two kinds of obstacles, } \\
\text { one is stationary obstacle in the road (appearing 10 times) and the other is a moving obstacle } \\
\text { (appearing 2 times). The obstacles are placed on the road at random spacing. The person in charge } \\
\text { of the experiment directs the participants to avoid the obstacles as narrowly as possible. }\end{array}$ \\
$\begin{array}{l}\text { Reaction to } \\
\text { unexpected } \\
\text { obstacles }\end{array}$ & $\begin{array}{l}\text { center of the road, which is half the width of the road. The unexpected obstacle, rectangular area } \\
\text { appears } 4 \text { times. The person in charge of the experiment directs the participants to escape from the } \\
\text { unexpected obstacle areas as soon as possible when they find themselves enclosed in it. }\end{array}$ \\
\hline $\begin{array}{l}\text { Overall operating } \\
\text { characteristics }\end{array}$ & $\begin{array}{l}\text { Other characteristics regarding operational ability and the level of understanding about the task are } \\
\text { extracted. }\end{array}$ \\
\hline
\end{tabular}




\section{$4 \cdot 3$ 評価基準}

操作の結果を次の評価基準に基づき分類した.

- 大まかな先を読んだ追従性（走路追従操作）

走路追従タスク（トラッキングタスク）では「ライン上の目印を追従しながら障害物回避する」指示 を与える．指示に従わず，中心ラインを離れるポイントがあるかという観点からデータを整理する.

・近くを見た細かな追従性（障害物回避操作）

障害物回避タスクでは「なるべく障害物に接近して近傍を通り抜ける」指示を与える。ここでは，回 避が行えたか，また「接近寸ること」「近傍を通ること」が守られているかという観点から傾向別に分類 する.

- 突然の障害物に対する対応（予期せ女危険回避操作）

失敗回避に関する反応では，「なるべく早く枠の中から出る」指示を与える.ここでは，反応の仕方 に着目し，傾向別に分類する.

\section{$4 \cdot 4$ 評価項目の決定}

分類結果を表 2 に示寸．これらの結果から，運転能力評価システムの評価項目を「走路追従タスク」「障害物回 避タスク」「危険地帯脱出タスク」とした．また，これらの他にもカーブや障害物をショートカット寸るものや障 害物を $2 つ$ 同時に回避するものなどがあったため，それらを「操作全般」の項目として 4 項目を抽出した。「走路 追従タスク」では正確性, 操作量, 左右の偏りを評価項目とした。この項目は運転行動では走路追従に相応し, 主に走路の知覚, 注意（選択性，持続性）に関連する。「障害物回避タスク」では正確性，ばらつき，回避失敗行 動の有無を評価項目とした。この項目は，運転行動では走路内の障害物認知や回避に相応し，主に走路や障害物 の知覚，注意（転動性，多方向性），回避の判断に関連する。「危険地帯脱出タスク」では脱出反応時間，脱出反 応の有無，脱出反応のばらつきを評価項目とした。この項目は運転行動では突然の飛び出しや環境変化など顕在 化しない危険の回避に相応し，主に状況変化の知覚，注意（転動性），瞬間的な判断に関連する．それぞれの評価 項目を定量化するための方針を表 3 に示す.

Table 2 Operational characteristics of elderly by the assessment system $(n=102)$

\begin{tabular}{|c|c|c|c|c|}
\hline Task & Criteria & Characteristics & Number (\%) & MMSE $(n=30)$ \\
\hline \multirow{4}{*}{$\begin{array}{l}\text { Road-following } \\
\text { ability }\end{array}$} & \multirow{2}{*}{ Smooth tracking } & Broken (From the start) & $13(12.7)$ & $4(13.3)$ \\
\hline & & Broken (From the cycle change-point) & $3(2.9)$ & $1(3.3)$ \\
\hline & \multirow[t]{2}{*}{ Tracking characteristics } & $\begin{array}{l}\text { No recovery onto the road after } \\
\text { avoiding obstacle }\end{array}$ & $15(14.7)$ & $8(26.7)$ \\
\hline & & Short cut taken while avoiding obstacle & $10(9.8)$ & $3(10.0)$ \\
\hline \multirow{3}{*}{$\begin{array}{l}\text { Obstacle avoidance } \\
\text { ability }\end{array}$} & \multirow{3}{*}{ Approach-avoidance } & Jerking forward and backward & $26(25.5)$ & $9(30.0)$ \\
\hline & & Swerving to the right and left & $13(12.7)$ & $1(3.3)$ \\
\hline & & $\begin{array}{l}\text { Jerking forward and backward and all } \\
\text { around }\end{array}$ & $6(5.9)$ & $2(6.7)$ \\
\hline \multirow{3}{*}{$\begin{array}{c}\text { Escape from } \\
\text { unexpected } \\
\text { dangerous area }\end{array}$} & Avoidance reaction & No reaction & $9(8.8)$ & $2(6.7)$ \\
\hline & \multirow{2}{*}{$\begin{array}{l}\text { Avoidance reaction } \\
\text { characteristics }\end{array}$} & Overreaction & $39(38.2)$ & $13(43.3)$ \\
\hline & & Slow reaction & $49(48.0)$ & $13(43.3)$ \\
\hline
\end{tabular}


Table 3 Evaluation items in the system for assessing driving ability

\begin{tabular}{|c|c|c|}
\hline Task & Item & Detail \\
\hline \multirow{3}{*}{$\begin{array}{l}\text { Road-following } \\
\text { (tracking) ability }\end{array}$} & Accuracy $S_{a}$ & $\begin{array}{l}\text { The value } S_{a} \text { is obtained as the integral of the difference between the target trajectory } f_{c}(z) \\
\text { and the operation trajectory } f(z) \text { divided by the length of the interval. } \\
\qquad S_{a}=\frac{1}{2}\left\{\int_{1700}^{2300}\left|f(z)-f_{c}(z)\right| d z+\int_{3200}^{3800}|f(z)-f(z)| d z\right\} \\
f_{c}(z)= \begin{cases}180 \times \sin (z \pi / 600) & 750 \leq z<2400 \\
200 \times \sin (z \pi / 600) & 2400 \leq z<3600 \\
150 \times \sin (z \pi / 600) & 3600 \leq z<4000\end{cases} \end{array}$ \\
\hline & $\begin{array}{l}\text { Manipulated } \\
\text { variable } \\
(\mathrm{MV}) f_{m v}\end{array}$ & $\begin{array}{l}\text { The value } f_{m v} \text { is obtained by dividing the trajectory line length by the target line length } L \text {. } \\
\qquad f_{m v}=\frac{1}{2}\left\{\frac{\int_{1700}^{2300} \sqrt{1+\left\{f^{\prime}(z)\right\}^{2}} d z}{L_{1}}+\frac{\int_{3200}^{3800} \sqrt{1+\left\{f^{\prime}(z)\right\}^{2}} d z}{L_{2}}\right\}\end{array}$ \\
\hline & Side bias $b_{s t}$ & 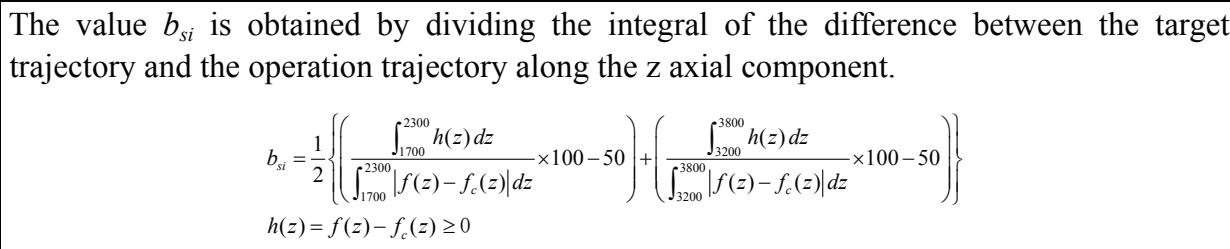 \\
\hline \multirow{2}{*}{$\begin{array}{l}\text { Obstacle } \\
\text { avoidance ability }\end{array}$} & Accuracy $a_{c}$ & $\begin{array}{l}\text { The value } a_{c} \text { is obtained by dividing the integral of the difference between the target } \\
\text { trajectory } f_{c}(z) \text { and the operation trajectory } f(z) \text { and the length of interval. The interval } \\
\text { length is obtained by } 100[\mathrm{~cm}] \text { in the } \mathrm{z} \text { axial from the obstacle to the front and rear. The } \\
\text { value } a \text { is the center and the value } r a \text { is the radius of the obstacle in } \mathrm{z} \text { axial. } \\
\qquad a_{c}=\frac{1}{5} \sum_{i=1}^{5} n_{c i}, \quad n_{c i}=\int_{a i-r a i-100}^{a i+r a i+100}\left|f(z)-f_{c}(z)\right| d z / 200\end{array}$ \\
\hline & $\begin{array}{l}\text { Fail } \\
\text { avoidance } \\
\text { behavior } e_{f}\end{array}$ & $\begin{array}{l}\text { The number } e_{f} \text { is obtained from the passing obstacle number. The passing criteria are from } \\
\text { within } 80 \% \text { visible line of the obstacle. The value } a \text { is the radius of obstacle in } \mathrm{z} \text { axis and } \\
\text { the value } b \text { is the radius of obstacle in } \mathrm{x} \text { axis. } \\
\qquad e_{f}=\sum_{i=1}^{5} n_{f}, \quad n_{f i}=\left\{\begin{array}{l}1 \\
\frac{z^{2}}{\frac{16}{25} a^{2}}+\frac{x^{2}}{\frac{16}{25} b^{2}} \leq 1 \\
\text { (otherwise) }\end{array}\right.\end{array}$ \\
\hline \multirow{2}{*}{$\begin{array}{l}\text { Escape from } \\
\text { unexpected } \\
\text { dangerous area }\end{array}$} & $\begin{array}{l}\text { Escape time } \\
t_{e}\end{array}$ & $\begin{array}{l}\text { The time } t_{e} \text { is the average of which obtained from the reaction time } t_{r t} \text { after the unexpected } \\
\text { three dangerous areas appear. } \\
\qquad t_{e}=\frac{1}{3} \sum_{i=1}^{3} t_{r i t}\end{array}$ \\
\hline & $\begin{array}{l}\text { Existence of } \\
\text { reaction } e_{r}\end{array}$ & $\begin{array}{l}\text { The value } e_{r} \text { is obtained from the number of times of slow reactions (more than } 2[\mathrm{sec}] \text { ), } \\
\text { after the unexpected three dangerous three areas appear. } \\
\qquad e_{r}=\sum_{i=1}^{3} n_{r i}, \quad n_{r i}= \begin{cases}1 & \left(t_{r i t} \geq 2\right) \\
0 & \left(t_{r i}<2\right)\end{cases} \end{array}$ \\
\hline Overall operating & $\begin{array}{l}\text { Existence of } \\
\text { shortcut } \\
\text { behavior } e_{s}\end{array}$ & $\begin{array}{l}\text { The value } e_{s} \text { is obtained from the number of failures to recover to the target path after } \\
\text { obstacle avoidance and escaping from an unexpected dangerous three areas } n_{s} \text {. } \\
\qquad e_{s}=\sum_{i=1}^{3} n_{s i}, n_{s i}= \begin{cases}1 & \text { (yellowarea) } \\
0 & \text { (otherwise) }\end{cases} \end{array}$ \\
\hline
\end{tabular}




\section{5. 運転能力評価システムの評価}

\section{$5 \cdot 1 \quad$ 運転能力評価システムの評価の概要}

開発した運転能力評価システムを用いて若年健常者と高齢健常者を対象とした評価実験を行い，前述の評価項 目の比較を行う．次に，高齢者の中でもパソコンの使用経験によってこれらの評価項目が影響を受けるから゙うか を調べる．さらに，認知機能に関連する指標である MMSE スコアとの相関を調心゙る.

\section{$5 \cdot 2$ 対象者}

対象者は 20 代若年健常者 15 名（男性 13 名，女性 2 名）（以下若年群），高齢者 92 名（平均年齢 $71.5 \pm 5.6(\mathrm{SD})$ 歳，男性 54 名，女性 38 名）である（以下高齢群）。高齢群は 4.2 節の評価項目を抽出した対象とは別の 65 歳以 上の男女であり，K町で実施した高齢者を対象とした健康診断を受診した者のうち，希望者の中から自動車の運 転免許を所有している者を優先して公募した. 高齢者群は実験期間が異なるために, 4.2 節に示した者と同一の実 験参加者に対して実施することは困難であった，そのため，実験協力者が異なっても問題がないように母集団や 公募の方法を統一した．なお，若年・高齢群ともに調査内容や質問を理解できかつ返答できることを条件とし， 研究の内容や趣旨について口頭および書面で十分説明したうえで本人の同意のもとに実施した.

\section{$5 \cdot 3$ システム評価実験の方法}

開発した評価システムを用いた操作能力の評価実験を行う．実験の前にタスクの説明と練習のためのセッショ ンが設けられており，対象者はあらかじめ実験の内容を知り，練習することができる．実験時間は説明や練習を 含めて 10 分程度で遂行できる. また, 高龃者を対象とした評価結果と基本属性や心身特性, 認知検查等の総合的 な指標との比較を行う。ここでは次の $2 つ の$ 項目についての調査および健診データを用いる.

(1)健康診断の項目のうち，属性，医学問診，身体測定，体力テスト，生活問診の認知機能検查(MMSE)を用い た.

(2)運転に関するアンケート調査の項目は免許の有無，取得年，運転頻度，日常における自動車の役割や運転行

動に対する自覚である. また，PCの操作経験についても確認した．

なお，健診データは ID で管理された連結可能匿名化されたデータを用いた．評価分析の方法は運転能力評価シ ステムの「走行追従タスク」「障害物回避タスク」「危険地帯脱出タスク」について, 若年群と高齢群について $t$ 検定を行う。有意水準は 5\%に設定した.

\section{$5 \cdot 4$ 評価実験分析結果}

若年群および高噛群を対象とした評価実験の結果を, 「走路追従タスク」「障害物回避タスク」「危険地帯脱出夕 スク」についてまとめる.

(1) 走路追従タスク

図 5 は走路追従タスクにおける追従正確性，左右の偏り，操作量についてそれらの点数を若年群，高齢群それ ぞれ算出したものである. 追従正確性, 操作量についてはスコア, 左右の偏りについてはプラス方向が右, マイ ナス方向が左のスコアを示したものである．追従正確性は高齢者の点数の平均值に有意な差が認められた $(\mathrm{t}(88.096)=11.429, \mathrm{p}=0.00)$. 左右の偏りについては高齢群の方が左に偏る傾向が見られたが，有意な差は認めら れなかった．また，操作量は高齢者の点数の平均值に有意な差が認められた $(\mathrm{t}(102.744)=5.464, \mathrm{p}=0.00)$.

(2) 障害物回避タスク

図 6 は障害物回避タスクにおける回避正確性，回避前後，回避左右についてそれらの点数を若年群，高齢群そ れぞれ算出したものである. 回避正確性はスコアが大きいほど目標軌跡からのずれが大きいことを表す．また， 回避前後はスコアが大きいほど障害物の前後に大きくよける傾向があり，回避左右はスコアが大きいほど障害物 の左右に大きくよける傾向を表す. 回避正確性は高齢群の点数の平均值に有意な差が認められた $\mathrm{t}(82.951)=10.551$, $\mathrm{p}=0.00)$. また, 回避前後 $(\mathrm{t}(82.951)=6.409, \mathrm{p}=0.00)$, 回避左右 $(\mathrm{t}(105)=3.470, \mathrm{p}=0.001)$ についても有意差が認めら れた。 


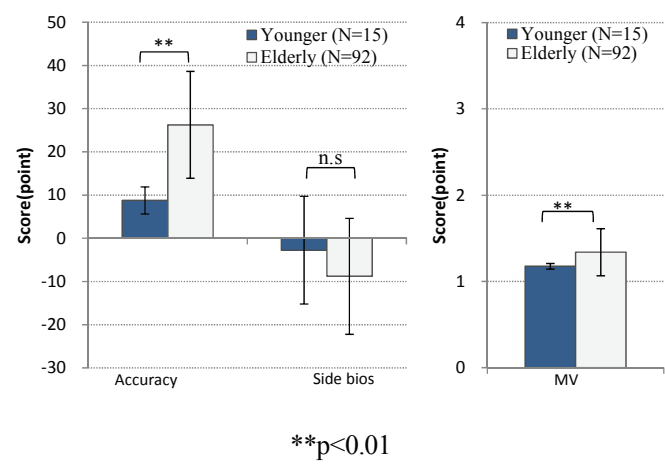

Fig. 5 The result of Road-following ability

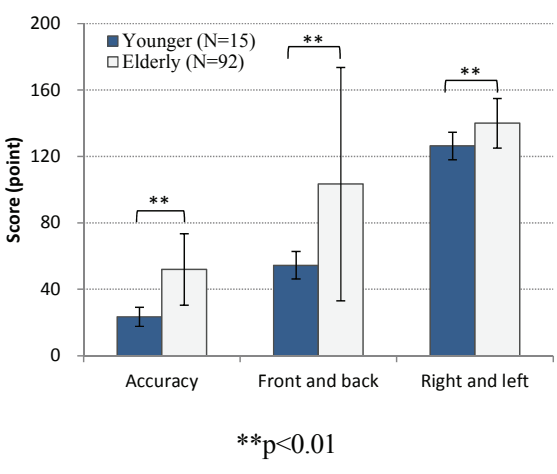

Fig. 6 The results of obstacle avoidance ability

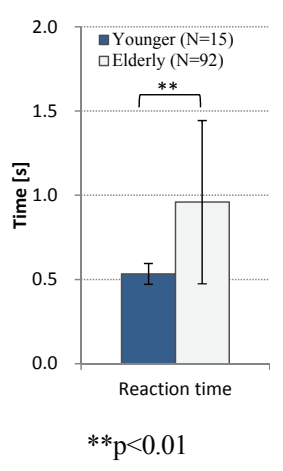

Fig. 7 Escaping from unexpected dangerous

(3) 危険地帯脱出タスク

図 7 は危険地帯脱出タスクにおける脱出反応時間を若年群，高齢群それぞれ算出したものである．脱出反応時 間は高齢群の反応時間の平均值に有意な差が認められた $(\mathrm{t}(103.372)=8.047, \mathrm{p}=0.00)$.

\section{$5 \cdot 5$ 評価実験の考察}

走路追従タスクでは若年群と比較し，高齢群は追従正確性，操作量において有意な低下が認められた．追従正 確性は，周辺視野予測を含む大まかな先を読んだ追従性を表すことから，これらの複合的な機能が低下している 可能性が示唆された. 障害物回避タスクでは若年群と比較し高齢群は追従正確性, 回避前後, 回避左右について 有意な低下が認められた．特に進行方向に大きくよける傾向と個人差が大きく, 速度を知覚しタイミングを計る 能力が低下している可能性が示唆された. 危険地帯脱出タスクでは高齢群の反応速度が有意に低いことが分かっ たことから，突然障害物が現れた時に鈍い反応を示す可能性が示唆された。

したがって，高齢者は運転に必要とされる注意の持続性（注意を一定時間持続すること）や転動性（注意を中 断し必要な刺激に注意転換する)，多方向性（一つの刺激に集中しつつ多方向にも注意をはらうこと）が低下する と考えられる. また，速度予測（見積）能力が低下寸ることによって判断が遅れる可能性が示された.

\section{$5 \cdot 6$ 操作の慣れの影響}

(1) 評価方法

属性やアンケート調查の結果, 若年群は寸ベてパーソナルコンピュータ (PC) やゲームの操作経験あったが, 高齢群については使用経験なし，ほとんど使わないが使用経験有りが $76 \%$ であり，操作に慣れていないことが予 測できた，そのため，はじめに PC の操作経験の有無が成績に与える影響について確認した.

(2) PC の使用経験の有無と評価結果

PC の使用経験が評価結果におよぼす影響を調べるために，高齢者のうち PC の使用経験群( $\mathrm{n}=23)$ と若年者群 $(\mathrm{n}=15)$ の比較を行った. その結果, 追従正確性の点数が有意に低く平均值に有意差が認められた $(\mathrm{t}(28.549)=6.467$, $\mathrm{p}=0.00)$. 左右への偏り, 操作量については有意な差は認められなかった。障害物回避については回避正確性 $(\mathrm{t}(27.985)=4.610, \mathrm{p}=0.00)$, 回避前後 $(\mathrm{t}(22.328)=2.186, \mathrm{p}=0.040))$ で有意な差が認められたが, 回避左右については 有意差が認められなかった．また，脱出反応時間については有意差が認められた $(\mathrm{t}(23.043)=3.602, \mathrm{P}=0.001)$. した がって, 「追従正確性」「障害物回避正確性」「回避前後」「危険地帯脱出反応時間」の指標において PC 操作経験 とは関係なく，高齢者の特性として取り扱うことが可能である. 


\section{6. 運転能力評価システムと高齢者の特性}

\section{$6 \cdot 1$ 運転能力評価と認知機能}

医学的認知機能検查と運転能力評価システムの各指標の関連性を調べるために，MMSE を用いた認知機能検 查の結果と運転能力評価システムの結果についての比較を行った.

(1) 評価方法

第 2 章の分類と同様に, MMSE スコアが 27 点 30 点の正常值（高群）と 26 点以下の軽度認知症疑い（認知症 などの認知障害がある可能性が高い 21 点以下を含む低群）に分類し，「走路追従タスク」「障害物回避タスク」

「危険地帯脱出タスク」について分析を行った.

(2) 認知機能検査とシステムによる評価結果

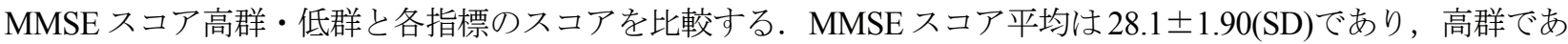
る 27 点以上は 68 名 $(73.9 \%)$, 低群である 26 点以下は 24 名 $(26.1 \%)$ であった，その結果，走路追従タスクの追従正 確性は高群が，それ以外については低群の成績が低かったが有意な差は認められなかった。

\section{$6 \cdot 2$ 認知機能に関する実験結果の考察}

本研究において， 65 歳以上の高齢者を対象に開発した運転能力システムを用いて運転能力評価を実施し，そ の評価項目と認知機能との相関を検討した。 その結果，簡易的な認知機能検査の一つである MMSE スコアと評 価項目には有意な相関が認められなかった。 この要因として，今回対象とした高齢者の MMSE スコアは比較的 高く, 著しい認知機能の低下が認められた者がいなかったため, 群間の差が認められなかったと考えられる. あるいは，MMSE スコアが高い高齢者の中にも運転能力が低下している人がおり，MMSE スコアが低い高齢者 の中にも運転能力が高い人が存在している可能性があるともいえる.

\section{$6 \cdot 3$ 運転能力の評価指標}

第 4 章で，各評価項目において若年群と高齢群に有意な差が認められたことを示したそそこで，本研究で用い た評価項目のスコアを単なる加齢によるものと区別し比較するために，それぞれの評価指標を式 1 に示す高齢者 の平均值を用いた偏差值として表すこととした.

$$
\mathrm{Z}_{i}=50+\frac{10\left(x_{e}-\mu_{e}\right)}{\sigma_{e}}
$$

ここで， $Z_{i}$ は各指標における高齢者のスコアの偏差值， $x_{e}$ は各指標のスコア， $\mu_{\mathrm{e}}$ は高齢者の平均スコア， $\sigma_{e}$ は高齢者のスコアの標準偏差である，図8に各評価項目における偏差值を示す，なお，図中にはMMSEスコア高 群である 27 点以上と低群 26 点以下については点数ごとに示した。但し，(a)，(c)，(d)，(e)，(f)，(g)は偏差值が 大きいほど成績すなわち関連する運転能力が低下していることを表わす．また，(b)は 50 を中心として，值が大 きい場合は右へ，小さい場合は左へ偏りがあることを表わす。

その結果，平均に有意な差は認められなかったものの，平均值から大きく外れた值の中に MMSE の低スコア の割合が多いことが分かった．そこで，高齢者の平均スコア $\mu_{e}$ を中心值とした 5 段階の尺度を設計した. 表 4 にこの尺度を用いた MMSE スコア 26 点以下と MMSE スコア 27〜30 点の各スコアの割合を示寸.この指標を用 いた分類によって，加齢では見分けがつかない能力低下が存在することが分かった．また，平均值の有意差は認 められなかったものの，障害物回避や予期せぬ危険回避の成績が低いケースに MMSE26 以下の割合が高いこと が分かった.

本研究ではこの指標について単なる加齢による機能低下を含む平均的な数值を基準として，それに対して著し い低下が認められた場合（Score 1）に，その項目の運転能力が低下していると判断することとした．これらの項 目が平均值より著しく低いということは，他の方法では補完できない運転能力の欠如を意味するため，安全な運 転行動ができない可能性があると判断できる. 


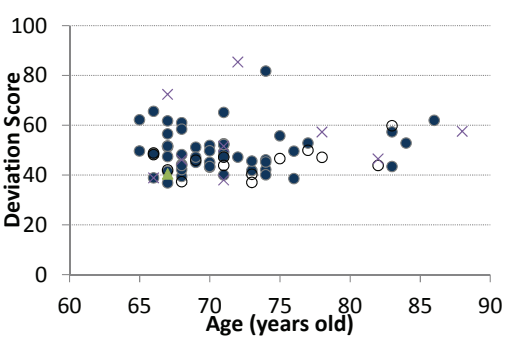

(a) Road-following accuracy

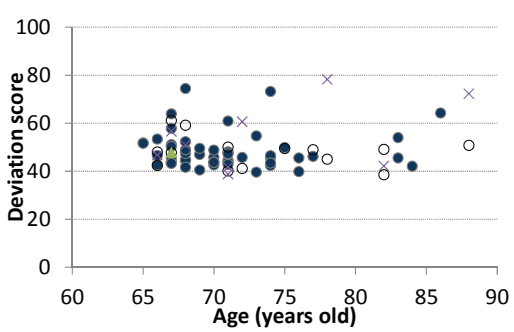

(d) Obstacle-avoidance accuracy

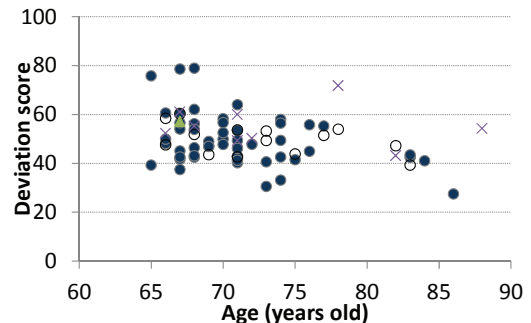

(b) Road-following side bias

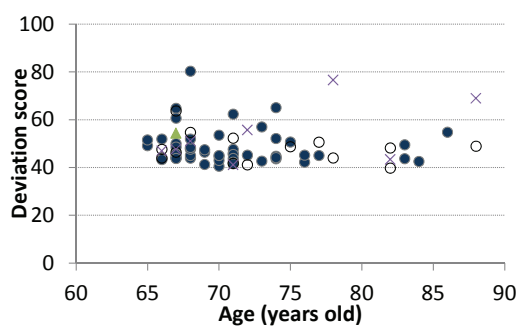

(e) Obstacle-avoidance accuracy, to front and rear

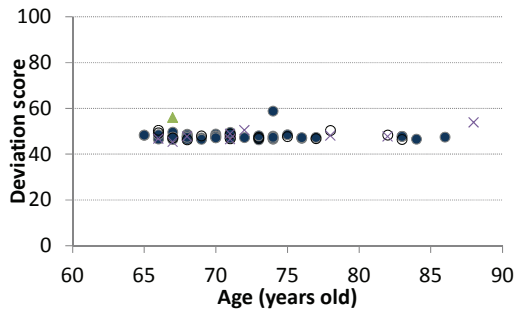

(g) Reaction time for escaping from unexpected dangerous

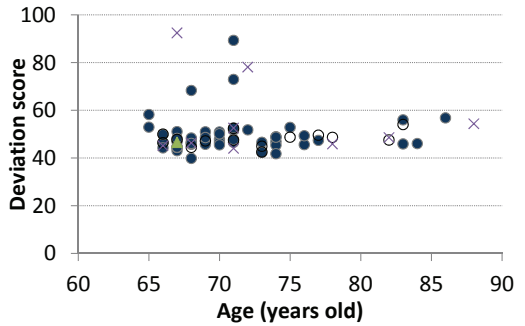

(c) Road-following MV

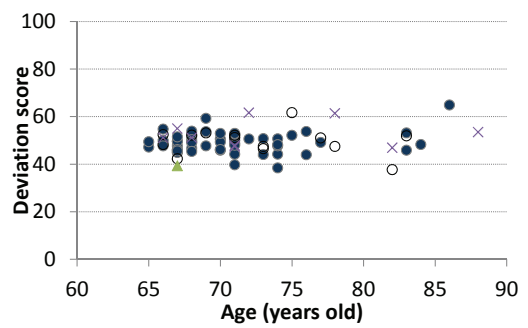

(f) Obstacle-avoidance accuracy, to the side

MMSE27 以上 $(\mathrm{N}=68) \quad$ OMMSE $26(\mathrm{~N}=14) \quad \times \operatorname{MMSE} 25(\mathrm{~N}=9) \quad \triangle \operatorname{MMSE} 23(\mathrm{~N}=1)$

Fig. 8 Relationship between index and age

Table 4 Evaluation index of the assessment system of driving ability

\begin{tabular}{|c|c|c|c|c|c|c|}
\hline & $\begin{array}{l}\text { MMSE } \\
\text { Score }\end{array}$ & $\begin{array}{c}\text { Score } 1 \\
\left(\sigma_{\mathrm{Sl}} \leqq-\sigma\right) \\
\text { Number }(\%)\end{array}$ & $\begin{array}{c}\text { Score } 2 \\
\left(-\sigma<\sigma_{\left.S_{2}<-0.5 \sigma\right)}\right. \\
\text { Number }(\%)\end{array}$ & $\begin{array}{c}\text { Score } 3 \\
\left(-0.5 \sigma \leqq \sigma_{\mathrm{S} 3} \leqq 0.5 \sigma\right) \\
\text { Number }(\%)\end{array}$ & $\begin{array}{c}\text { Score } 4 \\
\left(0.5 \sigma<\sigma_{S 4}<\sigma\right) \\
\text { Number }(\%)\end{array}$ & $\begin{array}{c}\text { Score } 5 \\
\left(\sigma \leqq \sigma_{\mathrm{S} 5}\right) \\
\text { Number }(\%)\end{array}$ \\
\hline \multirow{2}{*}{$\begin{array}{l}\text { Road-followin } \\
\text { g accuracy }\end{array}$} & $\geqq 27$ & $13(14.7)$ & $8(8.8)$ & $41(45.6)$ & $17(20.6)$ & $13(10.3)$ \\
\hline & $\leqq 26$ & $3(12.5)$ & $2(8.3)$ & $10(41.7)$ & $3(12.5)$ & $6(25.0)$ \\
\hline \multirow{2}{*}{$\begin{array}{l}\text { Road-followin } \\
\text { g side bios }\end{array}$} & $\geqq 27$ & $11(14.7)$ & $22(26.5)$ & $33(30.9)$ & $13(14.7)$ & $13(13.2)$ \\
\hline & $\leqq 26$ & $1(4.2)$ & $4(16.7)$ & $12(50.0)$ & $3(12.5)$ & $4(16.7)$ \\
\hline \multirow{2}{*}{$\begin{array}{l}\text { Road-followin } \\
\text { g MV }\end{array}$} & $\geqq 27$ & $6(5.9)$ & $6(7.4)$ & $58(61.8)$ & $21(23.5)$ & $1(1.5)$ \\
\hline & $\leqq 26$ & $2(8.3)$ & $1(4.2)$ & $16(66.7)$ & $5(20.8)$ & 0 \\
\hline \multirow{2}{*}{$\begin{array}{l}\text { Obstacle } \\
\text { avoidance } \\
\text { accuracy }\end{array}$} & $\geqq 27$ & $14(15.2)$ & $6(6.5)$ & $40(43.5)$ & $26(28.3)$ & $6(6.5)$ \\
\hline & $\leqq 26$ & $5(20.8)$ & $1(4.2)$ & $10(62.5)$ & $5(20.8)$ & $3(12.5)$ \\
\hline \multirow{2}{*}{$\begin{array}{l}\text { Obstacle } \\
\text { avoidance } \\
\text { accuracy, the } \\
\text { front and back }\end{array}$} & $\geqq 27$ & $9(9.8)$ & $4(4.3)$ & $55(59.8)$ & $24(26.1)$ & 0 \\
\hline & $\leqq 26$ & $3(12.5)$ & $1(4.2)$ & $15(62.5)$ & $5(20.8)$ & 0 \\
\hline \multirow{2}{*}{$\begin{array}{l}\text { Obstacle } \\
\text { avoidance } \\
\text { accuracy, the } \\
\text { side }\end{array}$} & $\geqq 27$ & $10(10.9)$ & 10 (10.9) & $47(51.1)$ & $15(16.3)$ & $10(10.9)$ \\
\hline & $\leqq 26$ & $4(16.7)$ & $3(12.5)$ & $12(50.0)$ & $2(8.3)$ & $3(12.5)$ \\
\hline \multirow{2}{*}{$\begin{array}{l}\text { Escape } \\
\text { reaction time } \\
\text { of unexpected } \\
\text { dangerous }\end{array}$} & $\geqq 27$ & $3(3.3)$ & $1(1.1)$ & $59(64.1)$ & $29(31.5)$ & 0 \\
\hline & $\leqq 26$ & $1(4.2)$ & $1(4.2)$ & $13(54.2)$ & $9(37.5)$ & 0 \\
\hline
\end{tabular}




\section{7. 結}

本研究では，高齢ドライバを対象とした運転能力評価システムの開発を行った．このシステムは，運転に必要 な能力のうち, 認知機能, 判断機能を総合的に測定するもので, 「走路追従」「障害物回避」「予期せぬ危険回避」 に関する能力を定量化するものである．まず，運転に必要と考えられる運転能力の検討を行い，運転能力評価シ ステムを開発した. 次に, 評価システムの評価項目を決定するために 102 名の高齢者を対象とした実験を実施し, 操作軌跡の分類を基に評価項目を決定した。 それらの評価項目に基づいて，さらに若年者 15 名，高齢者 92 名を 対象としたシステムの評価実験を行い，高齢者の操作特性を明らかにした．また，パソコンなどの情報機器の利 用が評価結果に与える影響について調べた. さらに, 認知機能の低下と評価結果の関連性を調べるために, MMSE スコアと評価項目の相関を調べ，各評価項目において平均值を中央值とした 5 段階の評価指標を作成した，その 結果，次のことが分かった.

- 走路追従に相応し, 知覚や注意機能（選択性, 持続性）を必要とする「走路追従タスク」では, 追従の正 確性や操作量について高齢群の成績が有意に低い.

- 走路内の障害物認知や回避行動に相応し，走路や障害物の知覚や注意機能（転動性，多方向性）を必要と する「障害物回避タスク」では，追従の正確性について高齢群の成績が有意に低い．また，高齢群は前後 に大きくよける傾向があり，操作対象の速度（スクロール速度）と障害物の速度予測ができていない可能 性が示唆された.

- 突然の飛び出しや環境変化などの顕在化しない危険の回避行動に相応し, 状況変化の知覚, 注意（転動 性），瞬間的な判断を必要と寸る「危険地帯脱出タスク」では，脱出反応時間について高齢群の成績が有 意に低い. 寸なわち，危険を察知してから状況判断にかかる時間が長くなる可能性が示された.

- 本研究で開発した運転能力システムでは，今回の実験参加者は医学的な認知機能（MMSE スコア 23 30） の成績が比較的高かったため, 有意な相関は認められなかった.

自動車は高齢者の移動生活を支え, 特に地方都市においては生命の維持にも関わる重要な道具であるため, 可 能な限り運転継続のための方策を検討する必要がある。本研究で開発した運転能力評価システムは, 運転継続 の判断を客観的に行い，安全な運転環境を提供するためのツールとして活用することを目指している．今後は， アルツハイマー病などの疾患により運転を断念した人を対象とした計測実験を行い, 認知機能に関する他の医 学的指標との関連性を調べるとともに, 実車走行との関連性を明らかにする予定である.

\section{謝 辞}

調査を行うにあたり東京都健康長寿医療センター研究所新開省二先生, 吉田裕人先生, 草津町保健センターの 皆さま, また, 実験に参加くださった皆さまに協力を頂いた。ここに感謝の意を表す，なお，本研究は科研費 (B)20300194「高齢運転者の運転断念に向けての評価法と社会的受容性に関寸る研究」の助成を受けて行われた.

\section{文献}

（1）高齢者運転適性ハンドブック，自動車技術会 高齢者運転適性研究委員会報告書 (2005).

（2）豊田泰孝, 繁信和恵, 池田学, “高齢者の自動車運転の実態”, 老年精神医学雑誌, Vol.19, 増刊号-I (2008), pp. 138-143.

（3）赤松幹之，“1. 運転中に何を見て，そして何を認知しているのか〜道路，交通，運転特性，そして高齢ドライバ〜 小特集 運転者の知覚・認知能力の診断と補償”, 映像メディア学会誌, Vol. 61, No.12 (2007), pp. 1682-1688.

(4) 池田学, “痴呆症高齢者の自動車運転と権利擁護に関寸る研究”, 長寿科学総合研究事業総合研究報告書 (2006).

（5）上村直人，諸郎陽子，“認知症と自動車免許”， medicina， Vol. 44， No.6 (2007), pp. 1154-1157.

（6）上村直人, 諸隈陽子, 掛田恭子, 下寺信次, 井上新平, 池田学, “認知症高齢者と自動車運転 運転継続の判断が 困難であった認知症患者 10 例の精神医学的考察”, 老年精神医学雑誌, Vol.16, No.7 (2005), pp. 822-830.

(7) 寺川智浩, 玉井顯, 池田学, “認知症高齢者の自動車運転に関するアンケート調査一アルツハイマー病患者の自動 車運転に対する患者と認知気の乘離に関する検討一”, 老年精神医学䧱誌，Vol.20, No.5 (2009), pp. 555-565. 
(8) 所正文, “高齢ドライバーの運転免許更新をめぐる問題”, 老年社会科学, Vol.30, No.1 (2008), pp. 98-105.

(9) 警察庁，“講習予備検査（認知機能検査）について”，http://www.npa.go.jp/annai/license_renewal/ninti/index.html (参照 日 2011 年 2 月 20 日).

（10）小竹元基，細川崇，宇治信孝，鎌田実，“高齢運転者の運転特性とその背景要因に関する研究（第 1 報，高齢者の 生活・身体特性と運転特性の関連性)”，日本機械学会論文集 C 編，Vol.70，No.709 (2005), pp. 124-131.

(11) 財団法人交通総合分析センター, “高齢者の交通事故分析一平成 12 年までの 10 年間の推移からみた特徵”, 財団法 人交通事故総合分析センター平成 14 年度自主研究 (2002).

(12) 財団法人交通総合分析センター, “事故からみた高齢ドライバーの運転特性に関する調査研究”, 財団法人交通事故 総合分析センター平成 16 年度自主研究 (2004).

(13) 財団法人交通総合分析センター, “操作の誤りによる交通事故の発生状況と発生要因の分析”, 財団法人交通事故総 合分析センター平成 22 年度自主研究 (2010).

(14) 宇野宏，“高齢ドライバの運転特性と支援技術”，高速道路と自動車，Vol.44， No.12 (2001), pp.45-48.

(15) 楊崢, 小林隆, 片山硬, “カーブ走行時の高齢ドライバの操作特性”, 自動車研究, Vol.22, No.7 (2000), pp.312-315.

(16) 宇野宏, “高齢ドライバの緊急回避特性に関する研究”, 自動車技術会論文集, Vol.32, No. 1 (2001), pp.113-118.

(17) 黒田勲, “ヒューマン・ファクターを探る一災害ゼロへの道を求めて”, 安全衛生新書 (1988).

(18) 三浦利章, “2. 運転時の視覚的注意と安全性 小特集 運転時の視覚的注意と安全性”, 映像情報メディア学会誌, Vol. 61, No.12 (2007), pp. 1689-1692.

(19) 中野倫明, 山本新, “3. 運転者の認知能力の診断技術 小特集 運転者の知覚・認知能力の診断と補償”, 映像メデ イア学会誌, Vo. 61, No. 12 (2007), pp. 1693-1696.

(20) Kaoru Inoue, Yuko Ito, Yumi Ikeda, Atsuko Tanimura, Keisuke Suzuki, Yoshiyuki Takahashi, Tadashi Suzuki, Madoka Fujimoto, Masahiro Tsuchijima, Takashi Komeda, "Trial Usage of Rehabilitation System: Simple Driving Simulator for the Driving Skill Evaluation of People with Cerebrovascular Disease: CVD", ICCHP 2006, LNCS Vol.4061 (2006), pp. 943-949.

（21）堀川悦夫，田野通保，大門每男，丸山将浩，岡村信行，松井敏史，荒井啓行，佐々木英忠，樹神學，“高齢者の認 知機能と運転行動の関係について一Trail Making Test と運転シミュレータを用いての検討一”, 東北大学医短部紀 要, Vol.11, No.1 (2002), pp. 25-36.

（22）三村將，三品誠，風間秀夫，“高齢者の運転能力と事故”, 老年精神医学杂倠誌, Vol.14, No.4 (2003), pp. $413-423$.

(23) 熊倉良雄, 並木勉, 菊屋喜与雄, “脳疾患を有する者の自動車運転状況と交通事故状況 一国立障害者リハビリテー ションセンター自動車訓練終了者について一”, 国際交通安全学会誌, Vol.29, No.2 (2004), pp. 132-140.

(24) 藤田佳男, 三村將, “認知症と運転”, 治療 Vol. 89, No. 11 (2007), pp. 3046-3053.

(25) J. D. Dawson, S. W. Uc, E. Dastrup, M. Rizzo, "Predictors of driving safety in early Alzheimer disease", Neurology Vol.72, No.6 (2009), pp. 521-527.

(26) Barbara Freund, Stefan Gravenstein, Rebecca Ferris, Bonnie L. Burke, Elias Shaheen, "Drawing Clocks and Driving Cars Use of Brief Tests of Cognition to Screen Driving Competency in Older Adults", Journal of General Internal Medicine Vol. 20 No. 3 (2005), pp. 240-244.

(27) 福居顯二, “臨床家のための認知症スクリーニング”, 藤美社 (2006), pp. 27-41. 